Portland State University

PDXScholar

9-17-1993

\title{
The Effects of Perceived Work Schedule Flexibility, Number of Hours Worked, and Type of Work Schedule on Work-Family Conflict
}

Tenora Dianne Grigsby

Portland State University

Follow this and additional works at: https://pdxscholar.library.pdx.edu/open_access_etds

Part of the Psychology Commons

Let us know how access to this document benefits you.

\section{Recommended Citation}

Grigsby, Tenora Dianne, "The Effects of Perceived Work Schedule Flexibility, Number of Hours Worked, and Type of Work Schedule on Work-Family Conflict" (1993). Dissertations and Theses. Paper 4606.

https://doi.org/10.15760/etd.6490

This Thesis is brought to you for free and open access. It has been accepted for inclusion in Dissertations and Theses by an authorized administrator of PDXScholar. Please contact us if we can make this document more accessible: pdxscholar@pdx.edu. 
AN ABSTRACT OF THE THESIS OF Tenora Dianne Grigsby for the Master of Science in Psychology presented September 17, 1993.

Title: The Effects of Perceived Work Schedule Flexibility, Number of Hours Worked, and Type of Work Schedule on Work-Family conflict.

APPROVED BY THE MEMBERS OF THE THESIS COMMITTEE:

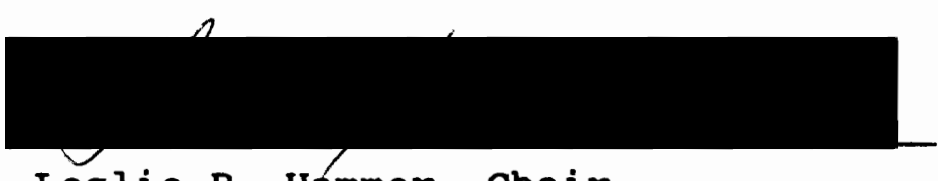

Leslie B. Hammer, chair

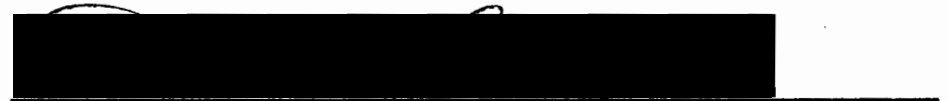

\section{Dean Frost}

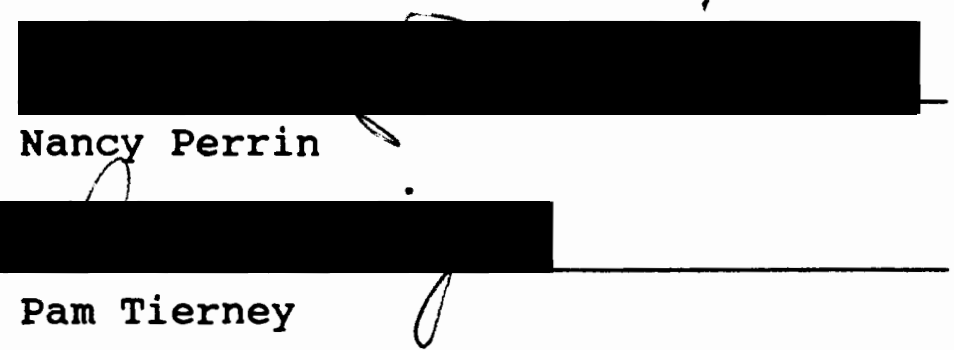

The interaction effects of perceived work schedule flexibility (PWSF) and the number of hours worked on workfamily conflict, and the interaction effects of PWSF and the type of work schedule on work-family conflict were investigated for employees of a regional bank headquartered in the Pacific Northwest. A 50\% response rate was obtained from a survey questionnaire administered to 2,000 randomly 
selected employees.

Hierarchial multiple regression analyses conducted on 526 subjects revealed no significant interaction effects for PWSF and type of work schedule. The interaction effect for PWSF and number of hours worked was not tested due to a significant correlation between number of hours worked and type of work schedule. However, significant main effects were found for both PWSF and the type of work schedule. Employees working a "part-time" schedule reported significantly lower work-family conflict than employees working a "standard" or "flexible" schedule. No significant differences were noted in work-family conflict between employees who worked "flexible" and "standard" work schedules. Overall, as PWSF increased, work-family conflict decreased. Employees who reported having "a lot" or "some" PWSF experienced significantly lower levels of work-family conflict than those employees who reported having "hardly any" or "no" PWSF.

Supplemental analyses were conducted on the number of hours worked variable. Results revealed that the number of hours worked made a unique contribution to the total variance in work-family conflict above and beyond that accounted for by type of work schedule. In contrast, both PWSF and number of hours worked contributed uniquely to the total variance in work-family conflict above and beyond that 
accounted for by each variable individually. Limitations of the research study are discussed and suggestions for future research are provided. 
THE EFFECTS OF PERCEIVED WORK SCHEDULE FLEXIBILITY, NUMBER OF HOURS WORKED, AND TYPE OF WORK SCHEDULE ON WORK-FAMILY CONFLICT

by

TENORA DIANNE GRIGSBY

A thesis submitted in partial fulfillment of the requirements for the degree of

\author{
MASTER OF SCIENCE \\ in \\ PSYCHOLOGY
}

Portland State University

1993 
TO THE OFFICE OF GRADUATE STUDIES:

The members of the Committee approve the thesis of Tenora Dianne Grigsby presented September 17, 1993.

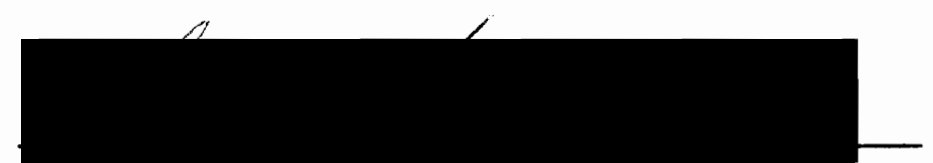

Leslie B. Hammer, Chair
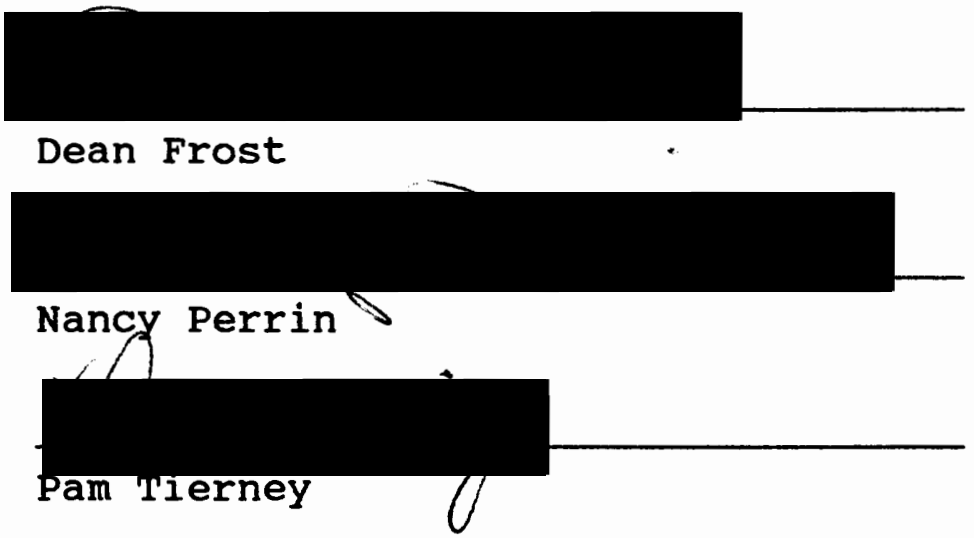

APPROYED :

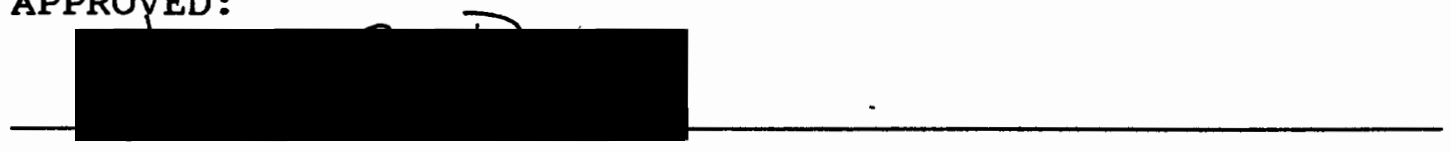

James A. Paulson, Chair, Department of Psychology

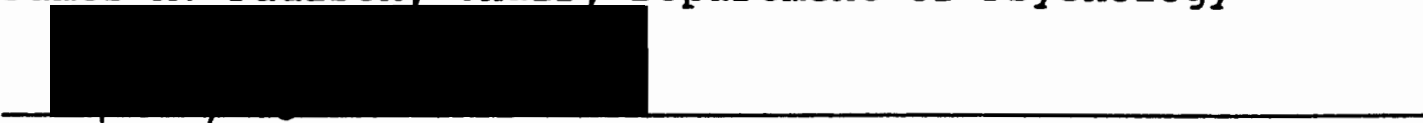

Roy w. Koch, Vice Provost for Graduate Studies and Research 
TABLE OF CONTENTS

LIST OF TABLES . . . . . . . . . . . . . . . . v v

LIST OF FIGURES . . . . . . . . . . . . . . . vii

CHAPTER

I INTRODUCTION . . . . . . . . . . . . . 1

Work-family Models . . . . . . . 3

Work-family Conflict Theory . . . . 5

Sources of Work-Family Conflict

Hours Worked and Work-family Conflict • 13

Work Schedules and Work-family Conflict 15

Perceived Work Schedule Flexibility . . 16

Rationale of Study . . . . . . . 18

Summary

Hypotheses

II METHOD . . . . . . . . . . . . 23

overview . . . . . . . . . . 23

subjects . . . . . . . . . 23

Survey instrument . . . . . . . . . 24

Demographic and Work

Characteristics

Work-family Conflict

Number of Hours Worked

Type of Work Schedule

Perceived Work Schedule Flexibility

Procedure . . . . . . . . . . 28

III RESULTS . . . . . . . . . . . . 30 
Descriptive Statistics . . . . . 31

Demographic and Work Characteristics

Work-Family Conflict

Statistical Analyses . . . . . . .

Coding of Variables for Regression Analysis

Test of Hypothesis 2

Final Regression Model

Additional Analyses on Number of Hours Worked

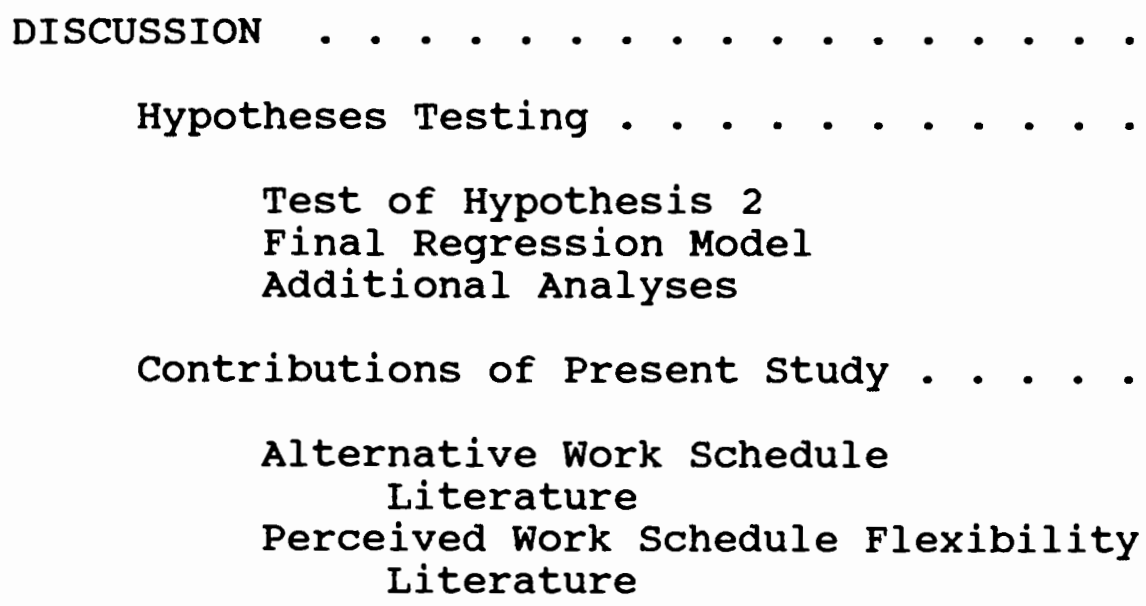

Test of Hypothesis 2

Final Regression Model

Additional Analyses

Contributions of Present Study . . . .

Alternative Work Schedule

Literature

Perceived Work Schedule Flexibility Literature

Limitations and Implications for Future

Research

Summary Comments . . . . . . . 64 


\section{LIST OF TABLES}

TABLE

PAGE

I Means and Standard Deviations of Personal

and work Characteristics for subject

Pool Based on Missing Values ( $N=164)$

and Subject Pool Based on Selection

Criteria $(\mathrm{N}=526)$. . . . . . . .

II Frequencies of Personal and Work

Characteristics for Subject Pool Based

on Missing Values $(\mathrm{N}=164)$ and Subject

Pool Based on Selection Criteria

$(\mathrm{N}=526)$ •

III Means and Standard Deviations for Work-Family Conflict by Type of Work Schedule and by Perceived Work Schedule Flexibility . . 36

IV Results of Regression Analyses of Work-

Family Conflict on Type of Work Schedule

and Perceived Work Schedule Flexibility

After Controlling for Demographic

Variables . . . . . . . . . . .

V Final Regression Model of Work-Family

Conflict on Type of Work Schedule and Perceived Work Schedule Flexibility . . 
VI Group Means Comparisons of Work-Family

Conflict for Total Number of Hours

Worked by Type of Work Schedule . . . 44

VII Partial Correlations- Work-Family Conflict . 45

VIII Chi Square Tests of Differences Between

Observed and Expected Levels of

Perceived Work Schedule Flexibility

by Type of Work Schedule . . . . . 48 


\section{LIST OF FIGURES}

FIGURE

PAGE

1. Work-Family Role Pressure Incompatibility - 7 
CHAPTER I

INTRODUCTION

Flexibility in the workplace is becoming a major concern in corporate America. Lifestyle changes have led to a significant increase in the amount of diversity in today's workplace in terms of age, gender, culture (race and ethnicity), demographics, education, disabilities, and values (Jamieson \& O'Mara, 1991). For example, increases in the number of females and minorities in the workforce, the number of single parent families, the number of dual career couples, and the number of families assuming primary responsibilities for the care of elderly parents or relatives have been documented by researchers and statisticians (Cicirelli, 1981; Jamieson \& O'Mara, 1991; Olmsted, 1983; U.S. Department of Labor, 1992). Companies are attempting to address the challenges and demands for flexibility created by this workforce diversity. One of the strategies used is the development and implementation of "family friendly" policies and programs in the workplace. Some examples of "family friendly" programs offered are leave of absence programs for educational, parental or personal reasons; dependent care referral services for children or elders, employee assistance programs to help 
with work and/or personal problems, and flexible or "cafeteria" benefit programs to reduce benefit costs, especially for dual career couples. In addition, flexible work arrangements, such as compressed work weeks and flextime, are another "family friendly" policy used by companies as a strategy to meet employees' needs for flexibility to help balance work-family demands. (Ahmadi, Raiszadeh, \& Wells, 1986; Buckley, Kicza, \& Crane, 1988; Christensen \& Staines, 1990; Dunham, Pierce \& Castaneda, 1987; McQuire \& Liro, 1987; Olmsted, 1983).

This study was part of a field research project conducted in a local financial institution to assess employee perceptions of alternative work schedules in the workplace. The purpose of the research study was two-fold: 1) to investigate the interaction of the effects of perceived work schedule flexibility and the number of hours worked on work-family conflict, and 2) to investigate the interaction of the effects of perceived work schedule flexibility and the type of work schedule on work-family conflict. Prior research has shown that work-family conflict is positively related to the number of hours worked (Greenhaus \& Beutell, 1985; Pleck, Staines \& Lang, 1980) and negatively related to job and life satisfaction (Pleck et al., 1980; Wiley, 1987). Likewise, prior research suggests that employees working traditional work schedules (i.e., 8 
a.m. to 5 p.m.) experience more interferences with personal/family activities than employees working nontraditional or alternative work schedules, e.g., compressed work weeks or flextime schedules (Dunham et al., 1987). However, few studies have specifically addressed the interaction between employees' perceptions of flexibility and the number of hours worked, or the interaction between employees' perceptions of flexibility and the type of schedule worked on the amount of work-family conflict experienced by employees.

\section{WORK-FAMILY MODELS}

Investigations into the dynamics and relationships of work and family domains have generated considerable interest. Researchers across a broad spectrum of professional disciplines in the social sciences are actively investigating work and family issues; for example, sociologists, family counselors, family therapists, and social, industrial/organizational and community psychologists. During the middle and late 1970's a shift appeared to have been made in the research focus. Instead of investigating the domains separately, research investigations began to focus on the linkages between work and family.

In a review of the literature, Zedeck and Mosier (1990) 
noted five main theoretical models that describe the relationship between life at work and life at home:

1. Spillover Theory. This model is based on the assumption that similarities exist between what occurs in the work environment and what occurs in the nonwork environment. Affective responses, positive or negative, which are experienced in one domain are carried over into the other domain.

2. Compensation Theory. In contrast with spillover theory, compensation theory assumes not only the existence of differences in what occurs in the work and nonwork domains but also an inverse relationship. Aspects in one domain are compensated for by what occurs in the other domain.

3. Segmentation Theory. This theory is based on the assumption that no overlap occurs between work and nonwork environments. Events that occur in one domain are separate and distinct from events that occur in the other domain.

4. Instrumental Theory. In contrast with segmentation theory, instrumental theory assumes the existence of a dependent relationship between work and nonwork environments. Events that occur in one domain are the means by which things are obtained in the other domain.

5. Conflict Theory. This theory is based on the assumption that incompatibilities exist between the roles, 
norms and requirements of the work and nonwork environments. Satisfaction or success in one domain requires sacrifice in the other.

In all five models, the individual, rather than the family, is used as the unit of measurement. Except for the segmentation model, all models assume a reciprocal relationship between the work and nonwork domains. However, work is viewed as having a more significant impact on the nonwork domain than the nonwork domain is viewed to have on the work domain. The present study focuses on one specific nonwork domain, the family.

\section{WORK-FAMILY CONFLICT THEORY}

The theoretical basis for the present research study was conflict theory. This model was chosen because the variables of interest in the present study place demands on an individual that may make it difficult to satisfy the requirements of work and family roles simultaneously. The definition most commonly used to operationally define work and family conflict is based on Kahn, Wolfe, Quinn, Snoek, and Rosenthal's (1964) work on role and interrole conflict. According to Kahn et al. (1964) role conflict is defined as the "simultaneous occurrence of two (or more) sets of pressures such that compliance with one would make more difficult compliance with the other" (p. 19). Kahn et al. 
(1964) defined interrole conflict as when " ... the role pressures associated with membership in one organization [or role] are in conflict with pressures stemming from membership in other groups [or roles]" (p.20). Combining these two definitions led Greenhaus and Beutell (1985) to operationally define work-family conflict as

a form of interrole conflict in which the role pressures from the work and family domains are mutually incompatible in some respects. That is, participation in the work (family) role is made more difficult by virtue of participation in the family (work) role (p. 77).

Using this definition as a basis for their literature review, Greenhaus and Beutell (1985) identified three major forms of work-family conflict: a) time-based conflict, b) strain-based conflict, and $c$ ) behavior-based conflict (see Figure 1). The assumptions upon which their work-family conflict model is based are described below:

1) Time-based Conflict. Conflicts between work and family roles are due to the characteristics associated with the performance of these roles that compete for an individual's time. For example, when the amount of time required to satisfactorily perform one's job duties competes with the amount of time needed to satisfactorily perform one's familial duties.

2) Strained-based conflict. Conflicts between work and family roles are due to the strains created by difficulties experienced in one role that are caused by performing in 


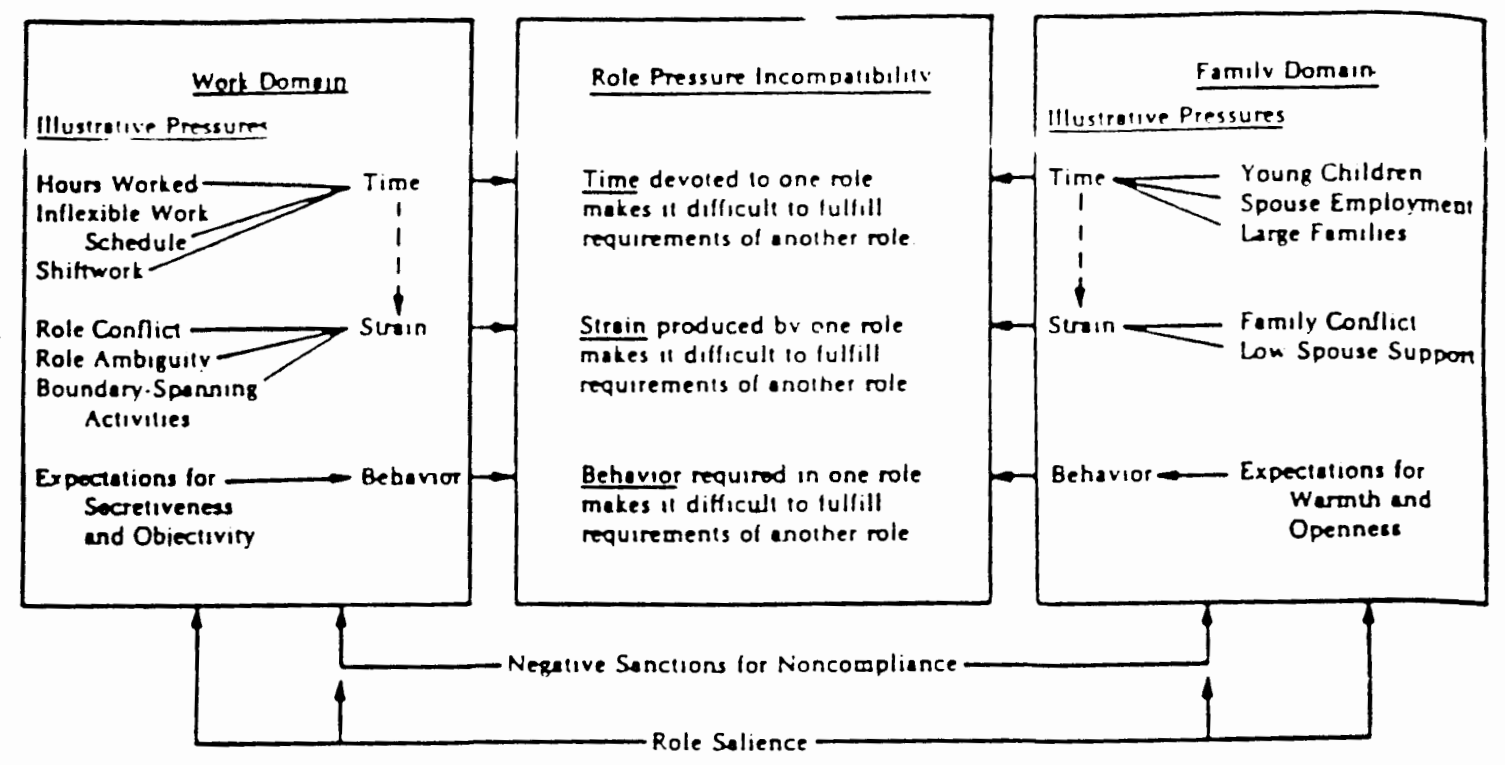

Figure 1. Work-family role pressure incompatibility. (Greenhaus and Beutell, 1985) 
another role. For example, having a job that requires frequent overnight travel and having small children at home who require care in your absence. The tension and stress caused by attempts to meet the expectations and demands of both the work and family roles results in strain- based conflict.

3) Behavior-based Conflict. Conflicts between work and family roles caused by behaviors required in one role that makes it difficult to meet the behavioral requirements of the other role. For example, you work in a fast pace environment with lots of activity and noise. Your job requires that you move quickly, make quick decisions, and meet short deadlines. Your elderly parents live with you in your home. You find yourself impatient at times with the amount of time it takes for them to perform simple tasks and make simple decisions. In order to successfully interact with your parents, you find you must slow down; move slower, speak slower, allow more time for decisions to be made. This behavior is the opposite of what is required of you to be successful on the job. This is behavior-based conflict. The present study was primarily concerned with time-based conflict. Time-based conflict arises in two forms (Greenhaus \& Beutell, 1985). First are conflicts caused by the time demands and pressures required in one role that make it physically impossible to meet the expectations 
associated with another role. Second are conflicts caused by time demands and pressures created by situations where attempts to meet the expectations of one role are impacted by one's preoccupation with performing in another role. For instance, you have agreed to pick up your spouse from the airport at 4 p.m.. You plan to leave the office at 3:30 p.m. to allow for rush hour traffic. You are notified your attendance is mandatory at a meeting to be held at 3 p.m.. Reluctantly you attend the meeting. However, your concentration on the issues being discussed are frequently interrupted with thoughts about your husband. For example, how long can you stay and still make it to the airport on time, what route can you take to cut down on travel time, what will be the reaction of your spouse if you are late, or what will be the reaction of your boss if you get up and leave the meeting early? While it is physically impossible for you to be in two places at one time, considerable effort and energy is expended in trying to figure out how the expectations and demands of both roles can be met. In this example, both forms of time-based conflict are present.

\section{Sources of Work-Family conflict}

As mentioned earlier, prior to the late 1970's, research investigations on work and family treated each domain separately. Role theory has been the theoretical foundation for much of the integrated research on work and 
family and work-family conflict. According to role theory, there are expectations and behaviors associated with the role(s) an individual assumes. When the expectations and behaviors associated with performing in multiple roles imposes demands for time, energy and commitment on the individual that are incompatible, conflicts arise. These role and interrole conflicts are the basis for many of the proposed models of work-family conflict found in the literature (Greenhaus \& Beutell, 1985; Kopelman, Greenhaus \& Connolly, 1983). For instance, there are expectations associated with one's work role just as there are expectations associated with one's family role. When the role expectations of the work role places demands on a person's time, energy or behavior that prevents the expectations of the family role from being met, some form of work-family conflict will result.

Work-related Sources of Work-Family Conflict. Previous research investigations have reported excessive work hours, role overload, schedule conflicts, inflexibility of schedules, job dissatisfaction, and job involvement to be work-related sources of conflict (Burke, 1988; Christensen \& Staines, 1990; Greenhaus, Bedeian, \& Mossholder, 1987; Kopelman et al., 1983; Pleck et al., 1980; Staines \& O'Connor, 1980). An example is Greenhaus, Parasuraman, Granrose, Rabinowitz and Beutell's (1989) study that looked 
at work domain pressures as sources of work-family conflict for dual career couples. In their study, they investigated the impact of four work domain pressures on two types of work-family conflict; time-based and strain-based conflict. The work pressures examined were work role stressors (role conflict, role ambiguity, and role overload); task characteristics (variety, autonomy, and complexity); work schedule characteristics (schedule inflexibility and workrelated travel); and work salience (job involvement and career priority). They found work role stressors accounted for a significant amount of the variance in time-based and strain-based work-family conflict for both men and women. of the work role stressors, role overload was the most consistent predictor of both forms of work-family conflict for both men and women. However, role ambiguity had a stronger impact on strain-based work-family conflict for men and time-based work-conflict for women. Also, task characteristics and work salience had a stronger impact on time-based work-family conflict for women than for men. However, the gender differences found in the amount of timebased work-family conflict disappeared when some of the demographic and work characteristics were statistically controlled.

Higgins, Duxbury and Irving (1992), also looked at work-family conflict in dual career families. They found 
that work conflict was the most significant predictor of work-family conflict. According to the authors, various work characteristics (i.e., hours worked per week, frequency of overtime, and inflexibility of work schedule) can create role overload and role conflict by placing extensive demands on an individual to participate in work activities that if performed create family role overload and family role conflict. In addition to work conflict, work expectations were found to be significant predictors of work-family conflict. For example, conflicts can arise when one is expected to be aggressive, ambitious, and analytical at work but at home one is expected to be warm, nurturing and intuitive.

Hours worked and work schedules are two of the workrelated sources of work-family conflict of primary interest in the present study and will be discussed in greater detail later in the paper.

\section{Family-Related Sources of Work-Family Conflict.}

Family-related sources of work-family conflict mentioned in the literature are marital status, the number and age of children in the home, the size of family, the number of hours worked per week by one's spouse, a couple's employment status (single or dual career), and the amount of spousal support (Kelly \& Voydanoffi, 1985; Loerch, Russell \& Rush, 1989). However, family-related sources of work-family 
conflict are not included as part of the research focus in the present study and thus will not be reviewed.

In summary, empirical evidence generally supports the time-based model of work-family conflict. Researchers appear to be in agreement that incompatibilities experienced by an individual due to the time pressures and demands of multiple roles can result in work-family conflict.

\section{HOURS WORKED AND WORK-FAMILY CONFLICT}

As mentioned earlier, the number of hours worked is a work-related source of conflict. Burke (1988) proposed a model of work-family conflict in his investigation of the antecedents and consequences of work-family conflict. The model hypothesized that work setting characteristics, like work load, supervision, autonomy, and work shift influenced perceived work stressors which in turn influenced workfamily conflict. Likewise, non-work setting characteristics, such as social support, marital and family relationships influenced non-work stressors which in turn influenced work-family conflict. Work stressors, non-work stressors and work-family conflict were posited to have a direct effect on various individual-level outcomes (e.g., job satisfaction, work alienation and burnout, and emotional and psychological well being). His findings generally supported Greenhaus and Beutell's (1985) time-based conflict 
model that showed work characteristics were more strongly related to work-family conflict than non-work characteristics.

Pleck et al. (1980), in their study on conflicts between work and family life, found the majority of the conflicts experienced by workers were related to excessive work time, work schedules, and fatigue and irritability caused by work. Job characteristics most strongly associated with work-family conflict were the number of hours worked, the amount of overtime, the work schedule, and the physically or psychologically demanding nature of the work involved. Parents reported more work-family conflicts than workers without children. Afternoon shift workers reported more work-family conflict than day and evening shifts. These findings also provided support for Greenhaus and Beutell's (1985) model of time-based conflict.

In summary, researchers are in agreement that the number of hours worked is a predictor of work-family conflict. Previous research clearly demonstrates that excessive hours worked and the frequency of overtime are work-related sources of work-family conflict.

WORK SCHEDULES AND WORK-FAMILY CONFLICT

The type of schedule worked is another work-related source of conflict. Anecdotal reports abound in the popular 
media regarding the use of alternative work schedules as a method for assisting employees in balancing work and family demands. Alternative work schedules are defined as nontraditional work schedules that depart from the traditional five day, forty hour work week $(5 / 40)$ schedule, which has been the standard in American industry (Ahmadi et al., $1986)$.

Research investigations on the benefits of alternative work schedules have reported flexible work schedules as being beneficial in the coordination of on-and-off the job responsibilities and in reducing interrole conflict ( Hicks \& Klimoski, 1981; Nord \& Costigan, 1973; Ralston, 1989). similarly, employees have reported reductions in the amount of interference between personal and family activities (Christensen \& Staines, 1990; Dunham et al., 1987).

In addition to personal benefits to the employee, research investigations also suggest that alternative work schedules provide employers with benefits such as increased organizational commitment, job retention, and employee recruitment (Duxbury \& Haines, 1991). Several researchers have suggested that future investigations involving alternative work schedules should be redirected to focus on comparisons of different flexible work schedules instead of comparisons between alternative and traditional work schedules (Christensen \& Staines, 1990; McGuire \& Liro, 
1987). The present study contributes to the limited knowledge in the research literature on the differences between alternative work schedules.

\section{PERCEIVED WORK SCHEDULE FLEXIBILITY}

Perceived work schedule flexibility is a variable often mentioned in the alternative work schedule literature as a plausible explanation for positive research findings on the effectiveness of such schedules (Christensen \& Staines, 1990). Perceived work schedule flexibility refers to one's subjective assessment of the flexibility of his or her work schedule. This suggests that perhaps it is not the particular type of schedule per se that reduces work-family conflict, but the perceived flexibility of one's work schedule that contributes to decreased levels of work-family conflict. For example, perceived flexibility was hypothesized to be one of the reasons for reported improvements in employees' abilities to reduce interference with work and family activities and to better coordinate onand-off the job responsibilities (Dunham et al., 1987; Ralston, 1989). It is important to note that alternative work schedules are not necessarily flexible work arrangements in and of themselves. In addition, it is important, for the purpose of this study, to distinguish "objective" work schedule flexibility from "subjective" 
work schedule flexibility. "Objective" flexibility refers to the organizational definition assigned by company policy to a specific work arrangement (i.e., standard, part-time, flexible, job share, etc.). "Subjective" work schedule flexibility refers to the degree of flexibility one perceives to be associated with their own particular work arrangement. For instance, an employee on a flextime schedule with no discretion to vary starting and ending times would most likely report higher "objective" flexibility and lower "subjective" flexibility than an employee working a standard full-time schedule with the autonomy to vary their schedule as needed. Likewise, an employee who works excessive hours but feels he/she has a lot of flexibility to handle personal/family responsibilities may report higher "subjective" flexibility than an employee who works fewer hours but views himself or herself as having no flexibility to handle personal/family responsibilities. The degree of "subjective" work schedule flexibility is therefore an employees' perception of the flexibility in their own work schedule to handle family/personal responsibilities, regardless of whether it is a traditional or alternative work schedule. In this study, "subjective" work schedule flexibility and perceived work schedule flexibility are synonymous terms. 
RATIONALE OF STUDY

\section{Summary}

Overall, empirical research generally supports the findings that hours worked and work schedules are workrelated sources of work-family conflict. Likewise, research generally supports the findings that demographic variables such as gender, marital status, age and number of children living at home are family-related sources of work-family conflict.

Excessive work hours and inflexible work schedules appear to be positively related to the amount of time-based work-family conflict one experiences (Pleck et al., 1980; wiley, 1987). This suggests that a reduction in work-family conflict should occur for employees allowed to work a flexible work schedule without excessive hours. Greenhaus and Beutell (1985) cautioned researchers against automatically drawing such a conclusion. They suggested that the amount of work-family conflict experienced may be due to a combination of the degree of perceived flexibility in the work schedule and the specific needs of the employee. The findings of Christensen and Staines (1990) provided additional support to the cautionary flag raised by Greenhaus and Beutell (1985). In their study of flextime as a viable solution to work-family conflict, they found that the degree of flexibility in the flextime schedule had the 
most impact on the amount of work-family conflict experienced. For example, the fewer the options for flexibility, the less effective the flextime schedule.

A criticism of the literature on both work-family conflict and alternative work schedules is the lack of research investigations specifically focused on workers' perceptions of flexibility. Flexibility is often touted as a plausible explanation for many of the positive results reported for studies conducted on alternative work schedules (Dunham et al., 1987; Ralston, 1989). Likewise, schedule inflexibility is touted as an explanation for an increase in the amount of work-family conflict experienced by an individual (Higgins et al., 1992; Pleck et al., 1980). However, previous research studies have not specifically addressed the relationship between the degree of perceived work schedule flexibility, excessive hours worked, the type of work schedule, and work-family conflict. Nor have previous research studies specifically focused on comparisons between different types of alternative work schedules in order to assess employee's perceptions of the amount of flexibility associated with a specific work schedule. As a result, there is a lack of empirical research that can be found to satisfactorily answer several questions stimulated by the comments of Greenhaus and Beutell (1985) and Christensen and Staines (1990). For 
example, what is the exact nature of the effect of perceived work schedule flexibility on work-family conflict? Is there an interactive effect such that the degree of perceived work schedule flexibility has a different effect for employees who work less hours than it does for employees who work more hours? For example, do employees who report low perceived work schedule flexibility and work a few hours experience more or less work-family conflict than employees who report high perceived work schedule flexibility and work a few hours? Do employees who report high perceived work schedule flexibility and work excessive hours experience more or less work-family conflict than employees who report low perceived work schedule flexibility and work excessive hours? Is there an interactive effect such that the degree of perceived work schedule flexibility has a different effect for employees who work alternative work schedules than it does for employees who work traditional schedules? For instance, do employees who report low perceived work schedule flexibility and work an alternative work schedule experience more or less work-family conflict than employees who report high perceived work schedule flexibility and work an alternative work schedule? Do employees who report high perceived work schedule flexibility and work a traditional schedule experience more or less work-family conflict than employees who report low perceived work schedule flexibility 
and work a traditional work schedule? These are the questions that have served as the impetus for the focus and direction of this study.

\section{Hypotheses}

Hypothesis 1. The amount of work-family conflict influenced by the number of hours worked will be moderated by the degree of perceived work schedule flexibility. When perceived work schedule flexibility is low, the number of hours worked will have an effect on work-family conflict such that high hours worked will be associated with higher work-family conflict than low hours worked. When perceived work schedule flexibility is high, work-family conflict will be lower than when perceived work schedule flexibility is low and the number of hours worked will have no effect.

Hypothesis 2. The amount of work-family conflict influenced by the type of work schedule will be moderated by the degree of perceived work schedule flexibility. When perceived work schedule flexibility is low, the type of work schedule will have an effect on work-family conflict such that the traditional work schedule will be associated with the highest level of work-family conflict, the part-time schedule will be associated with the next highest level of work-family conflict, and the flextime schedule will be associated with the third highest level of work-family conflict. When perceived work schedule flexibility is high, 
work-family conflict will be lower than when perceived work schedule flexibility is low and the type of work schedule will have no effect. 
CHAPTER II

METHOD

OVERVIEW

This study was part of a field research project for a single business interested in assessing employee perceptions of alternative work schedules. The business, a bank holding company, has branch offices, subsidiary banks and other financial operations located in 30 different states. All business operations are subject to the policies and procedures adopted by the holding company. Corporate personnel liaisons are assigned to each subsidiary's management team to communicate and assist them with personnel-related issues, policies and procedures. These liaisons were used as a primary resource throughout the study to gain the support of all subsidiaries.

\section{SUBJECTS}

The possible sample for the research project was limited by company management to 2,000 active employees, (16\% of the total employee population). Active employees were operationally defined as exempt and non-exempt employees who were classified as full-time, part-time, or special hourly. The term "exempt" refers to whether an 
employee is required to be paid for hours worked in excess of $40 \mathrm{hrs}$ per week. Non-exempt employees are paid overtime, exempt employees are not. Employees classified as on leave of absence or retired were excluded from the study population.

A computer random number generator program (Focus subroutine from Information Builders, Inc., NY)) was used to randomly select employees from an alphabetical listing of total active employees. Of the 2,000 surveys mailed to employees, $50 \%(\mathrm{~N}=999)$ were returned. Employee participation was voluntary.

Criteria for selection of subjects to be included in the present study were marital status (either married or single and living with a spouse/partner), and type of work schedule (either standard, part-time or flexible). Six hundred and seventy-nine employees met the above selection criteria. However, for analysis purposes, a sub-sample of 526 subjects were used due to missing values for some of the variables of interest. Further discussion of these missing values can be found in the results section of this report.

\section{SURVEY INSTRUMENT}

The survey questionnaire included 93 items. The survey was developed from information obtained in on-site interviews with employees from various organizational levels 
in the company and standardized measures of work family conflict, job involvement, family involvement, job satisfaction and life satisfaction (See Appendix A). Described below are the survey items used as measures in the study.

Demographic and Work Characteristics

Ten items were included in the survey to obtain demographic and personal characteristics such as age, gender, ethnic background, marital status and number of years married or living together, number of children in the home, and age of youngest and oldest child (questions \#1, $2,7-9,12,19-21$ and 23). Work characteristics such as job class, job grade, hours worked, work schedule, and work area were obtained by using 12 items (questions \#3-6, 10-11, and 13-18) .

Work-family Conflict

Goff, Mount and Jamison's (1990) 16 item work-family conflict scale, with an internal consistency reliability of $r=.88$, was used to measure work-family conflict. This scale was a modification of the Kopelman et al., (1983) 8 item interrole conflict scale that used a 5-point Likert scale response format to measure interrole conflict between work and family. The modification doubled the number of items involved by substituting the word "family" for the 
word "work" in the original scale. This resulted in an expansion of the original scale to 16 items; 8 items measuring work-to-family conflict and 8 items measuring family-to-work conflict (questions \#73-88).

\section{Number of Hours Worked}

The number of hours worked (questions \#15 and 17) were operationally defined as the number of actual hours worked per week, including overtime. Subjects were asked to indicate the "number of regular hours I actually work per week" and "if a non-exempt employee, on average how many hours of overtime (over $40 \mathrm{hrs}$ ) do you work per week?" Overtime hours were added to the actual number of hours worked for non-exempt employees to arrive at the total number of hours worked per week.

\section{Type of work Schedule}

Part-time work schedules are currently the only work schedules defined by formal organizational policy in addition to the traditional or standard full-time work schedule. Although alternative work schedules have not been incorporated formally into organizational policy, managers are allowed some discretion and latitude to establish work schedules to accomodate the needs of their business units. As a result, some managers in the bank are experimenting with alternative work schedules. Consequently, some 
business units have employees working various alternative work schedules, while other business units do not.

Subjects were asked to respond to question (\#11), "Based on the work schedules described in the cover letter (standard full-time, part-time exempt, part-time non-exempt, flexible hours, job sharing, compressed work week and other), which one of the following best describes your present work schedule?" The operational definition of the schedules included in the study are provided below:

1) Standard, full-time schedule. A work schedule where employees work a five day, forty hour work week (i.e., 8 a.m. -5 p.m.).

2) Part-time schedule. A work schedule where employees, work a specified number of hours below the standard full-time work schedule on a regular basis. Exempt employees (i.e., those not paid overtime pay for hours worked in excess of 40 hrs per week) and non-exempt employees (i.e., those paid overtime pay for hours worked in excess of 40 hrs per week) were both included in the parttime category.

3) Flexible schedule. A work schedule that permits flexible starting and quitting times, but requires a standard number of hours within a given time period each day. 


\section{Perceived work Schedule Flexibility}

Perceived work schedule flexibility (question \#10) is operationally defined as the degree of "subjective" flexibility one perceives in his/her work schedule to handle family/personal responsibilities. subjects were asked, "how much flexibility do you have in your work schedule to handle family/personal responsibilities?" The response scale used was a 4 point scale with 1 meaning a lot of flexibility and 4 meaning no flexibility at all.

\section{PROCEDURE}

Corporate personnel liaisons were used to inform executive management of the purpose of the study and to request their support prior to the distribution of the survey form. An article was written for the in-house magazine about current work-family practices in the company and described the research project to all employees, management and non-management.

Survey forms were distributed through the company's interoffice mail system. Instructions were included in the mailing that described the purpose of the study, the different types of work schedules included in the study, and the voluntary nature of employee participation. The steps taken to insure employees' confidentiality and the procedures to follow to be able to complete the survey on 
company time were also included. Subjects were instructed to complete surveys within a 10 day period and return them to Portland State University, Alternative Work Schedule Project, in the stamped, self addressed envelope provided. The morning after the surveys were mailed, a notice was placed on the corporate bulletin board, which is accessible to employees via their computer terminals, informing managers and employees that those selected to participate would be receiving surveys shortly. 
CHAPTER III

RESULTS

Preliminary analyses revealed a significant correlation between the number of hours worked and type of work schedule variables, $\underline{I}=.67, E(2,672)=274.53, \mathfrak{Q}<.0001$. Since $a$ major contribution of the present study was examining the differences between alternative work schedules instead of the differences between alternative work schedules and traditional or standard work schedules, the decision was made to not include the hours worked variable in the regression model, therefore Hypothesis 1 was not tested. Hierarchial multiple regression analyses were used to test the main and interaction effects of the type of work schedule and perceived work schedule flexibility on workfamily conflict after controlling for demographic variables.

As mentioned earlier, twenty-four percent of the subjects were excluded from the analyses performed in the present study because of missing values for items included in the work-family conflict scale. These missing values were primarily due to two items (\#75 and \#80). A comparison of descriptive statistics for the sub-sample $(N=526)$ and subjects with missing values $(N=164)$ is provided in Tables I and II. Missing values appeared to be evenly distributed 
among the different types of work schedules and the perceived work schedule flexibility categories. However, differences between the two subject pools were noted in gender, marital status, and number of children living at home (see Table II).

\section{DESCRIPTIVE STATISTICS}

Demographic and work Characteristics

Means, standard deviations and frequencies for the demographic and work characteristics of the sub-sample ( $\mathrm{N}=$ 526) used in the present study are displayed in Tables I and II.

Sixty-eight percent of the subjects were females $(\mathrm{N}=$ $360)$ and $32 \%$ were males $(\mathrm{N}=166)$. The average age of subjects was 39 years. Ninety percent reported their racial identity as white and $10 \%$ as non-white. Ninety-three percent were married and $7 \%$ were non-married. Forty-two percent had no children living at home, $26 \%$ had one child living at home, and $32 \%$ had two or more children living at home.

With regards to work characteristics, $48 \%$ of the employees in the sample were assigned to a support area and $52 \%$ were assigned to a line area. Seventy-nine percent worked full-time, $18 \%$ were part-time employees entitled to employee benefits, and $3 \%$ were part-time employees with no 
TABLE I

MEANS AND STANDARD DEVIATIONS OF PERSONAL AND WORK CHARACTERISTICS FOR SUBJECT POOL BASED ON

MISSING VALUES $(\mathrm{N}=164)$ AND SUBJECT POOL

BASED ON SELECTION CRITERIA ( $\mathrm{N}=526)$

\begin{tabular}{|c|c|c|c|c|}
\hline & \multicolumn{2}{|c|}{$\begin{array}{l}\text { Missing Values } \\
\underline{n}=164\end{array}$} & \multicolumn{2}{|c|}{$\begin{array}{l}\text { Sample } \\
\mathrm{n}=526\end{array}$} \\
\hline & $\underline{\mathbf{M}}$ & s.d. & M & s.d. \\
\hline Age & 39.9 & 10.92 & 39.03 & 9.74 \\
\hline $\begin{array}{l}\text { Number of } \\
\text { children }\end{array}$ & .77 & .98 & 1.01 & 1.10 \\
\hline Job Tenure & 8.72 & 4.56 & 10.17 & 8.66 \\
\hline
\end{tabular}

Note. $\quad M=$ Mean, s.d. = Standard deviation, $\mathrm{n}=$ number of subjects. 
TABLE II

FREQUENCIES FOR PERSONAL AND WORK CHARACTERISTICS FOR SUBJECT POOL BASED ON MISSING VALUES ( $\mathrm{N}=164)$ AND SUBJECT POOL BASED ON SELECTION CRITERIA $(\mathrm{N}=526)$

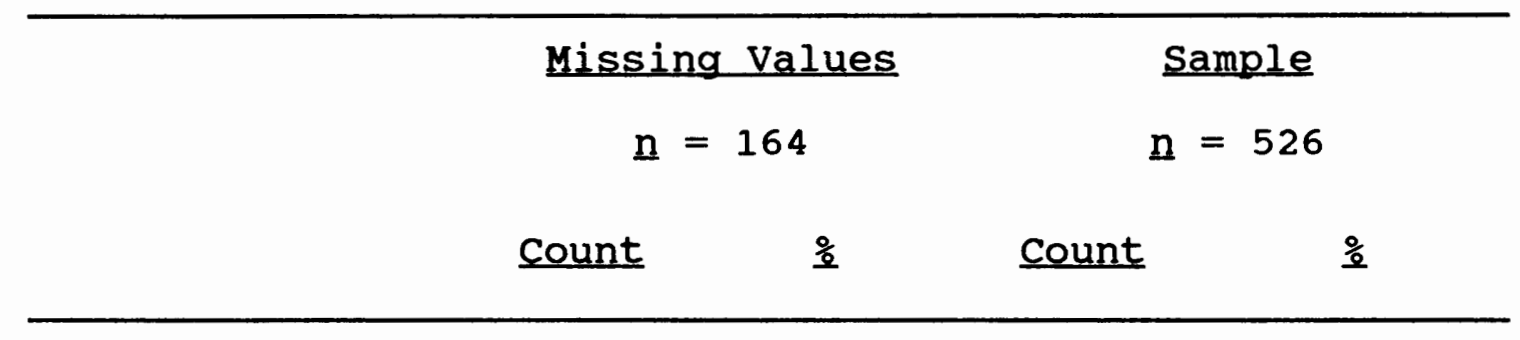

Sex

$\begin{array}{lcccc}\text { Male } & 34 & 20.70 & 166 & 31.60 \\ \text { Female } & 130 & 79.30 & 360 & 68.40\end{array}$

Ethnic

$\begin{array}{lrrrr}\text { White } & 147 & 90.20 & 474 & 90.50 \\ \text { Non-white } & 17 & 9.80 & 152 & 9.50\end{array}$

Marital Status

$\begin{array}{lrrrr}\text { Married } & 146 & 89.00 & 491 & 93.03 \\ \text { Non-married } & 18 & 11.00 & 35 & 6.70\end{array}$

\# of Children

$\begin{array}{lllll}\text { None } & 88 & 54.30 & 229 & 41.90 \\ \geq 1 & 76 & 45.70 & 306 & 58.10\end{array}$


TABLE II

FREQUENCIES FOR PERSONAL AND WORK CHARACTERISTICS FOR SUBJECT POOL BASED ON MISSING VALUES $(N=164)$ AND SUBJECT POOL BASED ON SELECTION CRITERIA $(N=526)$ (continued)

\begin{tabular}{|c|c|c|c|c|}
\hline & \multicolumn{2}{|c|}{$\begin{array}{c}\text { Missing Values } \\
\underline{n}=164\end{array}$} & \multicolumn{2}{|c|}{$\begin{array}{l}\text { Sample } \\
\underline{n}=526\end{array}$} \\
\hline & count & 是 & count & 奠 \\
\hline \multicolumn{5}{|l|}{ PWSF } \\
\hline A lot & 32 & 19.5 & 110 & 20.9 \\
\hline Some & 92 & 56.1 & 302 & 57.4 \\
\hline Hardly any & 31 & 18.9 & 93 & 17.7 \\
\hline None & 9 & 5.5 & 21 & 4.0 \\
\hline \multicolumn{5}{|l|}{ Work schedule } \\
\hline standard & 123 & 75.0 & 384 & 73.0 \\
\hline Part-time & 31 & 18.9 & 98 & 18.6 \\
\hline Flexible & 10 & 6.1 & 44 & 8.4 \\
\hline
\end{tabular}

Note. PWSF $=$ Perceived Work Schedule Flexibility 
employee benefits. Four percent of the employees in the sample were at the Senior Vice President level or above in the organizational structure, $12 \%$ were Vice Presidents, $49 \%$ were exempt employees below the vice presidential level and $35 \%$ were non-exempt employees. The average length of time with the company was 10.2 years.

Twenty-one percent of the employees in the sample reported "a lot" of perceived work schedule flexibility, 57\% reported "some" flexibility, $18 \%$ reported "hardly any" flexibility, and $4 \%$ reported "none". With regards to type of work schedule, seventy-three percent of the employees in the sample worked a "standard" work schedule, 19\% worked a "part-time" schedule, and $8 \%$ worked a "flexible" schedule.

\section{Work-Family conflict}

The mean for work-family conflict for the entire sample population was $M=2.732$. Females reported experiencing higher levels of work-family conflict than their male counterparts. Work-family conflict means were $\underline{M}=2.759$ for females and $M=2.674$ for males.

Means and standard deviations for work-family conflict by type of work schedule and by perceived work schedule flexibility are provided in Table III. Employees who worked a "standard" work schedule reported the highest level of work-family conflict, while those who worked a "part-time" schedule reported the lowest level of work-family conflict. 
TABLE III

MEANS AND STANDARD DEVIATIONS FOR WORK-FAMILY CONFLICT BY TYPE OF WORK SCHEDULE AND BY PERCEIVED

WORK SCHEDULE FLEXIBILITY

\begin{tabular}{|c|c|c|c|}
\hline & \multicolumn{2}{|c|}{ Work Family } & Conflict \\
\hline & $\underline{\mathbf{M}}$ & s.d. & $\underline{n}$ \\
\hline \multicolumn{4}{|c|}{ Work Schedule } \\
\hline standard & 2.82 & .63 & 375 \\
\hline Part-time & 2.40 & .69 & 96 \\
\hline Flexible & 2.70 & .75 & 44 \\
\hline \multicolumn{4}{|c|}{ Perceived Work schedule } \\
\hline \multicolumn{4}{|c|}{ Flexibility } \\
\hline A lot & 2.45 & .70 & 109 \\
\hline Some & 2.72 & .62 & 296 \\
\hline Hardly any & 3.00 & .65 & 91 \\
\hline None & 3.20 & .70 & 19 \\
\hline
\end{tabular}

Note. $\underline{\underline{n}}=515 ; 1=$ low work-family conflict; $5=$ high work-family conflict. Work-family conflict mean for the entire sample population was $\underline{M}=2.732$, s.d. $=.6732$ 
As the level of perceived work schedule flexibility decreased the level of work-family conflict increased. Employees with "a lot" or "some" flexibility reported having less work-family conflict than those employees who had "hardly any" or "none" flexibility.

\section{STATISTICAL ANALYSES}

\section{Coding of Variables for Regression Analysis}

Dummy coding was used to code the demographic variables (marital status, ethnic background, and sex), the three types of work schedules (standard, part-time and flexible), and the four levels of perceived work schedule flexibility (a lot, some, hardly any, and none). The "standard" work schedule was coded as the control group for work schedules. The "none" category was coded as the control group for perceived work schedule flexibility.

The demographic variables age and number of children were entered as continuous variables. Six variables were created to code the interaction term for type of work schedule and perceived work schedule flexibility. Although the anchors on the Likert scale ranged from strongly agree to strongly disagree, ratings were recoded so that 1 equaled strongly disagree and 5 equaled strongly agree. A new variable was created to reflect the mean score of the 16 items used to measure work-family conflict. This scale 
score was entered in the model as a continuous variable.

Test of Hypothesis 2

A preliminary regression analysis was conducted to determine the relationship between the five demographic variables and work-family conflict. The total amount of variance accounted for in work-family conflict by these variables was $5 \%, \mathrm{R}^{2}=.050, E(5,505)=5.28, \mathfrak{p}<.0001$. Age was the only variable with a significant beta, $\underline{t}=$ $-4.385, \mathrm{p}<.0001$. In the first step of the regression analysis, age was entered in the model and all other demographic variables were dropped. In step 2, the main effect of type of work schedule was examined by entering the coded vectors for the work schedule variable along with age (see Table IV). The increase in $\mathrm{R}^{2}$ due to work schedule was significant, $\Delta \mathrm{R}^{2}=.078, \underline{F}(3,509)=22.493, \mathrm{p}<.0001$. In step 3, perceived work schedule flexibility was added to the model. The increase in $\mathrm{R}^{2}$ due to perceived work schedule flexibility was also significant, $\Delta R^{2}=.057, \underline{F}(6,506)=$ $11.641, \mathrm{p}<.0001$. In the last step, the interaction effect of work schedule and perceived work schedule flexibility was examined by adding the coded vectors for the interaction term to the model. The increment in $R^{2}(.017)$ was not significant, therefore Hypothesis 2 was not supported. Consequently, the interaction term was dropped from the final model. 
TABLE IV

RESULTS OF REGRESSION ANALYSES OF WORK-FAMILY CONFLICT

ON TYPE OF WORK SCHEDULE AND PERCEIVED WORK

SCHEDULE FLEXIBILITY AFTER CONTROLLING FOR DEMOGRAPHIC VARIABLES

\begin{tabular}{clcc} 
Steps & \multicolumn{1}{c}{ Variables Entered } & \multicolumn{1}{c}{ E-Value } \\
\hline 1 & Age * & .042 & $22.411^{* * *}$ b \\
2 & Age and B c & .078 & $22.493^{* * *}$ \\
3 & Age, B and C & .057 & $11.641^{* * *}$ \\
4 & Age, B, C and B*C & .017 & 2.09 \\
\hline
\end{tabular}

- Age was the only variable with a significant beta when controlling for demographic variables, $t=-4.385, p \leq .0001$. ${ }^{b * *} \mathrm{P} \leq .0001 ;{ }^{\circ} \mathrm{B}=$ Type of Work Schedule; ${ }^{\mathrm{a}} \mathrm{C}=$ Perceived Work Schedule Flexibility; ${ }^{B} * \mathrm{C}=$ Interaction of Type of Work Schedule and Perceived Work Schedule Flexibility; $\mathrm{n}=512$. 
Final Regression Model

The overall $R^{2}$ for the final model was .177 which was significant, $E(6,506)=18.092, \mathrm{p}<.0001$. The beta coefficients, $t$-values, and probabilities for the final regression model discussed below are provided in Table $\mathrm{V}$.

Demographic Variables. The beta for age was significant (see Table V). As age increased the amount of work-family conflict reported decreased.

Type of Work Schedule. The comparison between the "part-time" and "standard " work schedules was found to be significant (refer to Table V). However, the comparison between the "flexible" and "standard" work schedules was not significant. The work schedule variable was then recoded and the regression recomputed so that a comparison could be made between the "part-time" and "flexible" work schedules. The beta for this comparison was also significant, beta = $.166, \underline{t}=3.557, \underline{p}=\leq .001$. Work-family conflict was significantly lower for employees who worked "part-time" schedules when compared to employees who worked "flexible" or "standard" schedules. However, the amount of work-family conflict reported by employees working "flexible" and "standard" work schedules was not significantly different. See Table III for descriptive statistics for work-family conflict for each of the work schedules. 
TABLE V

FINAL REGRESSION MODEL OF WORK-FAMILY CONFLICT ON TYPE OF WORK SCHEDULE AND PERCEIVED

WORK SCHEDULE FLEXIBILITY

Variable

Age

Work Schedule

Part-time vs Standard

Flexible vs Standard

PWSF

A lot vs none

$-.351$

$-3.717$

$\leq .001$

Some vs none

$-.298$

$-2.780$

$\leq .01$

Hardly any vs none

$-.064$

$-.723$

n.s.

Note. PWSF = Perceived work schedule flexibility;

n.s. = not significant; $\underline{n}=512$. 
Perceived Work schedule Flexibility. An examination of the t-tests associated with the betas representing comparisons among the perceived work schedule categories revealed significant beta's for the comparisons of "a lot of" and "some" flexibility with the "none" flexibility category on work-family conflict (see Table V). However, no significant differences were found for the comparison between the "hardly any" and "none" categories. The perceived work schedule variable was then recoded to make comparisons between the "a lot" flexibility category and the "some" and "hardly any" categories. Although not part of the full model and not reported in the table, significant beta's were found for both the comparisons (beta $=.125, \underline{t}=$ $2.418, \underline{p}<.05$ for the contrast between "some" perceived work schedule flexibility and "a lot" of flexibility; beta = $.262, t=5.228, \underline{p} \leq .0001$ for the contrast between "hardly any" perceived work schedule flexibility and "a lot" of perceived work schedule flexibility). Work-family conflict was significantly higher for employees with "some" perceived work schedule flexibility as compared to those with "a lot " of flexibility. On the other hand, employees in the "some" category had significantly lower work-family conflict than those in the "hardly any" category. There was no significant difference in work-family conflict for those in the "hardly any" and "none" categories. Descriptive 
statistics for work-family conflict for each of the perceived work schedule flexibility categories are displayed in Table III.

\section{Additional Analyses on Number of Hours Worked}

The lack of a significant finding in the amount of work-family conflict for the comparison between the "flexible" and "standard" schedules raised questions about the relationship of number of hours worked and work-family conflict. Previous research has suggested that flexible schedules reduce work-family conflict, therefore significant differences were expected between the "flexible" and "standard" work schedule groups. Because no significant differences were found between the groups, group mean comparisons were conducted to determine whether there were any significant differences in the number of hours worked by employees in the "flexible" and "standard" work schedule groups. T-tests performed on the group means revealed no significant differences in the average number of hours worked per week by employees (see Table VI).

Partial correlations for work-family conflict and the study variables were also examined (refer to Table VII). The results showed that the number of hours worked made a unique contribution to the total variance in work-family conflict above and beyond that accounted for by type of work schedule, $\Delta \mathrm{R}^{2}=.028, \underline{\mathrm{F}}(3,507)=15.255, \mathrm{p} \leq 0001$. In 
TABLE VI

GROUP MEANS COMPARISONS OF WORK-FAMILY CONFLICT FOR TOTAL NUMBER OF HOURS WORKED BY TYPE OF WORK SCHEDULE

\section{Work Family Conflict Total Hours}

Type of Work

Schedule

Standard vs

Part-time

Standard vs

Flexible

Part-time vs

Flexible
$\underline{\underline{M}}$

t-value
$16.48^{*}$

46.890 vs 28.989

1.77

Note: $M=$ Mean, TOTHRS $=$ Average number of hours worked per week; ${ }^{*} \mathrm{P} \leq .0001$. 
TABLE VII

PARTIAL CORRELATIONS - WORK-FAMILY CONFLICT

Variable of Interest Variable Removed

$\mathrm{R}^{2}$

F-value

Work Schedule

Hours Worked

PWSF

Hours Worked
Hours worked

Work Schedule

Hours Worked

PWSF

.005

.028

.070

.070
1.468

$15.255^{\star}$

$13.888^{*}$

$41.647^{*}$

Note. PWSF $=$ Perceived Work Schedule Flexibility.

$" \mathfrak{p} \leq .0001, \mathrm{n}=510$. 
contrast, type of work schedule did not account for any unique amount of variance after controlling for the number of hours worked. The partial $R^{2}$ of work-family conflict and total hours worked after removing perceived work schedule flexibility, $\Delta \mathrm{R}^{2}=.070, E(4,506)=41.647, \mathrm{p} \leq .0001$, and of work-family conflict and perceived work schedule flexibility after removing total hours worked, $\Delta \mathbf{R}^{2}=.070, E(4,506)=$ $13.888, p \leq .0001$, showed both variables were contributing uniquely to the total variance in work-family conflict.

A Chi square test was also performed on the $3 \times 4$ table (work schedule by perceived work schedule flexibility) to determine whether significant differences existed between the observed and expected levels of perceived work schedule flexibility for the different work scheduling groups (see Table VIII). These frequencies differed significantly from those expected by chance across the different types of work schedules, $\chi^{2}(6, \mathrm{~N}=526)=15.644, \mathrm{p} \leq .05$. Post hoc $\chi^{2}$ tests were performed to determine which work schedule distribution patterns differed. The results showed that the patterns of perceived work schedule flexibility when comparing employees working a "part-time" schedule and those working a "standard" schedule were significantly different, $\chi^{2}(3, \mathrm{~N}=482)=11.530 \mathrm{p} \leq .01$. Contrary to expectations, no significant differences were found in the distribution 
TABLE VIII

CHI SQUARE TESTS OF DIFFERENCES BETWEEN OBSERVED AND EXPECTED LEVELS OF PERCEIVED WORK SCHEDULE FLEXIBILITY BY TYPE OF WORK SCHEDULE

\begin{tabular}{|c|c|c|c|c|}
\hline $\begin{array}{l}\text { Flexible } \\
\text { Schedule }\end{array}$ & A lot & Some & Hardly Any & None \\
\hline \multicolumn{5}{|l|}{ standard } \\
\hline Observed & 67.0 & 229.0 & 68.0 & 20.0 \\
\hline Expected & 80.3 & 220.5 & 67.9 & 15.3 \\
\hline Row Pct & 17.4 & 59.6 & 17.7 & 5.2 \\
\hline \multicolumn{5}{|l|}{ Part-time } \\
\hline Observed & 30.0 & 48.0 & 19.0 & 1.0 \\
\hline Expected & 20.5 & 56.3 & 17.3 & 3.9 \\
\hline Row Pct & 30.6 & 49.0 & 19.4 & 1.0 \\
\hline \multicolumn{5}{|l|}{ Flexible } \\
\hline Observed & 13.0 & 25.0 & 6.0 & 0.0 \\
\hline Expected & 9.2 & 25.3 & 7.8 & 1.8 \\
\hline Row Pct & 29.5 & 56.8 & 13.6 & 0 \\
\hline
\end{tabular}

Note, Row Pct $=$ Row Percent. Overall $\chi^{2}(6, N=526)=$ $15.644, \mathrm{~g} \leq .05$ 
patterns of perceived work schedule flexibility for employees working a "part-time" schedule and those working a "flexible" schedule (see Table VIII). 
CHAPTER IV

DISCUSSION

The present study's results showed that work-family conflict was significantly lower for employees who worked "part-time" schedules when compared to those who worked "flexible" or "standard" work schedules. In addition, as the degree of perceived work schedule flexibility increased, the amount of work-family conflict reported by employees decreased. Employees who reported having the lowest workfamily conflict were those employees who perceived themselves as having "a lot" or "some" flexibility in their work schedule.

\section{HYPOTHESES TESTING}

\section{Test of Hypothesis 2}

The hypothesized significant interaction effect of perceived work schedule flexibility and type of work schedule on the amount of work-family conflict experienced by employees was not supported by the research findings (Hypothesis 2). Thus, how flexible one perceives their work schedule to be does not moderate the effect of the type of work schedule on the amount of work-family conflict experienced by an individual. Rather, it is the main 
effects of the type of work schedule and the degree of perceived work schedule flexibility that are significant predictors of work-family conflict.

Supplementary analyses were performed examining the effects of the number of hours worked on work-family conflict to gain a better understanding of these unexpected results. The results of these analyses are presented after the discussion of the final regression model.

\section{Final Regression Model}

Although the main effects and covariate were significant, only $18 \%$ of the total variance in work-family conflict was accounted for by age, type of work schedule and the amount of perceived work schedule flexibility. This suggests that there are other variables not included in the final model contributing to the amount of work-family conflict experienced by employees. The demographic variable age, while important, accounted for only $4 \%$ of the total variance.

Age. The covariate age was found to have a significant negative relationship with the amount of work-family conflict experienced by employees. This finding supports earlier research results that show younger employees experience more work-family conflict than their older counterparts (Greenhaus \& Beutell, 1985; Pleck et al., $1980)$. 
Work schedule. Work-family conflict for employees working a "part-time" work schedule was significantly lower than that for employees working a "standard" or "flexible" work schedule. Contrary to Hypothesis 2, employees who worked "standard" or "flexible" schedules appeared to experience very similar levels of work-family conflict. The lack of a significant difference in work-family conflict for the comparison between "flexible" and "standard" schedules was both unexpected and disturbing. A plausible explanation for these non-significant findings may be the small sample size in the flexible category $(N=44)$ as compared to the other groups.

Previous research findings on alternative work schedules have shown that alternative or flexible schedules are effective in reducing the amount of work-family conflict experienced by employees. These studies have reported flexible work schedules as being beneficial in the coordination of on-and-off the job responsibilities, in reducing interrole conflict, and in reducing the amount of interference between personal and family activities (Christensen \& Staines, 1990; Dunham et al., 1987; Hicks \& Klimoski, 1981; Nord \& Costigan, 1973; Ralston, 1989). In the present study "part-time" and "flexible" schedules are defined by the organization as being alternative or flexible work schedules. The results of the present study are only 
partially supportive of earlier research findings on flexible work schedules and their impact on reducing workfamily conflict.

Perceived work schedule Flexibility. The results of the main effect of perceived work schedule flexibility on work-family conflict were quite interesting. Work-family conflict was lowest for employees who felt they had "a lot" of perceived work schedule flexibility and highest for those who felt they had "none" flexibility. The amount of workfamily conflict reported by employees who had "a lot" of perceived work schedule flexibility was significantly lower than the work-family conflict for employees with "some" perceived work schedule flexibility. Similarly, employees who reported having "some" perceived work schedule flexibility had significantly lower work-family conflict than those who reported having "hardly any" or "none". In contrast, the levels of work-family conflict for employees who had "hardly any" or "none" flexibility were very similar. To summarize, work-family conflict decreased as the degree of perceived work schedule flexibility increased. This finding of reduced work-family conflict for employees with a lot of flexibility is generally supportive of previous research. Christensen and Staines' (1990) research on the impact of flextime schedules on work family conflict found that it was the degree of flexibility in the work 
schedule that had the most impact on the amount of workfamily conflict experienced by employees and not the type of flextime schedule. In their study, comparisions were made of the amount of work-family conflict experienced by employees working flextime schedules that had different start and end times. The results of the present study expands the research literature that investigates the impact of flexible work schedules on work-family conflict as well as contributes to the limited research literature that specifically examines the differences between types of alternative work schedules. In addition, the present study examines the impact of employees' perceptions of perceived work schedule flexibility on work-family conflict for employees who work different types of work schedules.

\section{Aditional Analyses}

Number of Hours Worked. Although the decision was made to not test Hypothesis 1 due to the significant correlation between number of hours worked and type of work schedule, some interesting findings were revealed in the additional analyses performed on the number of hours worked. For example, no significant differences were found in the total number of hours worked between the "flexible" and "standard" schedules. As expected, "part-time" employees were found to work significantly fewer hours than "flexible" and "standard" employees. Work-family conflict was 
significantly lower for "part-time" employees than it was for "standard" and "flexible" employees. In addition, the number of hours worked made a unique contribution to the total amount of variance in work-family conflict above and beyond that accounted for by the type of work schedule.

These findings suggests that "flexible" schedules that require an individual to work as many hours as those who work a "standard" schedule do not decrease the amount of work-family conflict experienced by employees. These results also imply that the number of hours worked may be a better predictor of the amount of work-family conflict experienced by employees than the type of work schedule.

Perceived work Schedule Flexibility. Perceived work schedule flexibility was found to contribute to the amount of work-family conflict experienced by employees above and beyond that contributed by the number of hours worked. Although the hypothesized interaction between perceived work schedule flexibility and type of work schedule was not supported by the results, some support was found for the importance of the distinction made earlier between "subjective" and "objective" work schedule flexibility. "Objective" work schedule flexibility refers to the organizational definition assigned by company policy to a specific work arrangement. "Subjective" work schedule flexibility refers to the degree of flexibility one 
perceives to be associated with their own particular work schedule. For instance, by definition, a "part-time" schedule is defined by policy in most organizations as an alternative or flexible schedule (i.e., objective flexibility). In the present study, "part-time" employees worked significantly fewer hours than employees on "flexible" and "standard" schedules, as well as reported significantly lower levels of work-family conflict. Based on these findings, one would expect similar findings with regards to the levels of perceived work schedule flexibility when making comparisons between the work schedule groups. For example, the distribution patterns of perceived work schedule flexibility should be significantly different for employees working a "part-time" schedule when compared to employees working either a "standard" or a "flexible" schedule. On the other hand, no significant differences should be found in the distribution patterns of perceived work schedule flexibility for employees working a "standard" schedule and those working a "flexible" schedule. Contrary to expectations, the results of the post-hoc $\chi^{2}$ analyses revealed no significant differences in the distribution patterns of perceived work schedule flexibility for employees working a "part-time" schedule and those working a "flexible" schedule. A plausible explanation for this finding between "part-time" and "flexible" employees may be 
the earlier distinction between "objective and subjective" flexibility. For instance, a "part-time" employee who is not allowed any latitude or flexibility at all by management to change the days on which they are scheduled to work may report lower perceptions of flexibility than an employee on a "flexible" schedule who is allowed some autonomy with regards to their work schedule. In addition, there may be outside factors impacting "part-time" employees" perceptions of flexibility, such as a second job, elder or dependent care responsibilities, or going to school.

\section{CONTRIBUTIONS OF PRESENT STUDY}

The present study makes two major contributions to the research literature.

\section{Alternative Work Schedule Literature}

With regards to the Iiterature on alternative work schedules, the present study examined differences between alternative work schedules (i.e., "part-time" versus "flexible") as well as examined the differences between alternative and traditional work schedules (i.e., "parttime" and "flexible" versus "standard"). The present study's focus on the comparisons between alternative work schedules instead of just the comparison of alternative work schedules to traditional work schedules was in direct response to suggestions made by previous researchers for the 
direction of future investigations involving alternative work schedules. The present study demonstrated that this approach has merit and that significant differences do exist in the amount of work-family conflict experienced by employees who are working two different types of alternative work schedules. Contrary to previous research findings, the present study showed alternative work schedules by themselves do not reduce the amount of work-family conflict experienced by employees. Rather, other variables, such as the number of hours worked and the degree of perceived work schedule flexibility, also need to be taken into consideration.

Perceived work Schedule Flexibility Literature

with regards to the research literature on perceived work schedule flexibility, the present study showed the importance of the effects of employees' perceptions of work schedule flexibility on the amount of work-family conflict reported. Currently, research that has specifically focused on employees' perceptions of the amount of flexibility associated with a specific work schedule is very limited. The present study expands the present body of knowledge by demonstrating that the degree of flexibility perceived by employees to be associated with their work schedule is a significant predictor of the amount of work-family conflict experienced. In addition, the present study shows that 
these perceptions influence the amount of work-family conflict reported by employees irrespective of whether they are working an alternative or traditional work schedule.

\section{LIMITATIONS AND IMPLICATIONS FOR FUTURE RESEARCH}

There are several limitations of the present study which makes one question the validity of the finding of a non-significant interaction between perceived work schedule flexibility and the type of work schedule.

First, the study lacked multiple measures to assess employees' perceptions of perceived work schedule flexibility. For example, only one item was used in the present study to measure employees' perceptions of flexibility. The non-significant interaction may have been due to an inadequate measurement of the construct of perceived work schedule flexibility. Future research should involve the use of a number of items to assess employees' perceptions of flexibility that could be combined to form a "flexibility scale". For instance, future investigations could use a methodology for measuring perceived work schedule flexibility similar to that used to measure workfamily conflict.

Second, the large number of missing values found in the items used to compute the work-family conflict scale score reduced the subject pool by $24 \%$. While the missing values 
appeared to be evenly distributed across work schedules, the impact of the reduction in the subject pool was a smaller sample size. Again, a plausible explanation for the lack of support for the hypothesized significant interaction may have been the lack of power associated with the statistical tests used. The power of a test depends on three factors, the alpha level, the difference between the two means being tested, and the sample size. Power, therefore, is a function of sample size, i.e., the larger the sample size, the more power due to the fact that the standard error decreases as the sample size increases. In the present study, the interaction between perceived schedule flexibility and type of work schedule may have been substantial but not recognized as significant due to the lack of power resulting from the small sample size in some of the flexible work schedule cells, for example, only 13 employees were in the cell for "a lot" of perceived work schedule flexibility, and zero were in the "none" cell (refer to Table VIII).

Third, generalizability of the results is limited to employees at the bank. Although, employees were randomly selected to participate in the study, no random assignment to work schedule groups could be performed since this was a field study. The present study also used a survey research design and not a quasi-experimental design. similar to most 
survey research, measurements were based on the subjective responses of the study participants and the study results may have been influenced by "self-selection". For example, surveys were not received from 50\% of the employees selected to participate in the study. The characteristics of these employees may have differed in important ways from those employees who did elect to return their surveys. Future research should include quasi-experimental designs with both objective and subjective measurements which would allow researchers to draw some causal inferences, although not as sound or as certain as those drawn from a true experiment. One of the major limitations of survey research is that only relationship data can be collected. In addition to the above, certain demographic characteristics of the subject pool also limited the generalizability and interpretation of the findings, e.g., $91 \%$ of the subjects were white.

Fourth, the cross-sectional nature of the study may have contributed to the low amount of variance in workfamily conflict accounted for by demographic variables. The fact that the average age of subjects in the present study was 39 years and $42 \%$ of the subjects had no children living at home may have unduly influenced the research results. Future research investigations should include longitudinal experimental designs that allow for the measurement of workfamily conflict at different time periods over an extended 
period of time.

Fifth, only $18 \%$ of the total variance in work-family conflict was accounted for by type of work schedule and perceived work schedule flexibility. This leaves $82 \%$ of the total variance in work-family conflict unexplained. Plausible explanations for the variance not explained in work-family conflict may be that the amount of work-family conflict experienced by employees is greatly influenced by other contextual factors in addition to perceptions of work schedule flexibility and type of work schedule, such as role conflict, role ambiguity, role overload, organizational culture, company policies, and superior-subordinate relationships.

Since the theorectical basis for the work-family conflict used in the present study is role theory, it is not unreasonable to expect role conflict (i.e., a dual reporting relationship, role overload (i.e., more work tasks assigned than one can physically complete during normal work hours), or role ambiguity (i.e., lack of clarity about assigned job tasks and responsibilities) in the work environment to contribute to the amount of work-family conflict experienced by employees.

In addition, the quality of the supervisor-employee relationship and the availability of resources in the work environment should not be overlooked. Employees who 
perceive their supervisor as sensitive to both their work and nonwork needs, and willing to "flex" the rules when potential conflicts arise between work and nonwork responsibilities, may experience less work-family conflict than those employees. who view their supervisor to be insensitive and "unbending". Leigh, Lucas and Woodman (1988), examined the effects of perceived organizational factors on role stress and job attitude relationships. They found that efforts directed toward developing a positive psychological climate and a management control system that is perceived favorable by employees improves employee job performance and job attitudes. Employees who perceived themselves in a work environment with a positive psychological climate and low management control also reported the least amount of role stress. Employees who reported having low levels of role stress reported having high levels of satisfaction in their work and nonwork lives. Role stress was operationally defined as the amount of role conflict and role ambiguity experienced by employees. Psychological climate was operationlly defined as the mean scale score reported by employees on five dimensions: 1) the individual autonomy afforded employees by management while on the job, 2) the amount of structure imposed by management on job positions and on the people in those positions, 3) management's reward orientation for good 
performance, 4) the amount of consideration, warmth and support shown by management to employees, and 5) management's orientation towards the development and progressiveness of employees. Perception of management control was defined as the employee's perception of external events that influence one's behavior.

In addition to contextual factors in the work environment, external factors and resource availability in the nonwork environment may also contribute uniquely to the amount of work-family conflict experienced by employees. For example, employees with primary responsibility for dependent care (i.e., elder or child) without any backup resources available to cover unexpected or unplanned events (i.e., illness or injury) may experience more work-family conflict than employees who have access to an extended family for support when such situations occur. Also, in today's economic environment, it is not uncommon for an individual who is not employed on a full-time basis to have to work more than one part-time job in order to meet financial obligations which also places extra demands on efforts to balance personal and family responsibilities. Future research needs to be directed at examining which of these contextual factors, internal and external, such as those above, account for the remaining $82 \%$ of unexplained variance in work-family conflict. 


\section{SUMMARY COMMENTS}

The concept of workplace flexibility and how to incorporate flexibility into organizations continues to command a lot of attention from the popular media. Flexibility has come to be viewed as a panacea by management to address the challenges they face associated with helping employees balance work and family demands. The results of the present study are generally supportive of the conclusions drawn in previous research studies that have attributed reductions in interferences with work and family activities to employees' perceptions of increased flexibility and the use of alternative work schedules (Dunham et al., 1987; Ralston, 1989). Similar to Christensen and Staines (1990), the results clearly showed that the degree of flexibility in the work schedule had the most impact on the amount of work-family conflict experienced. Based on these findings, it appears that the caution given by Greenhaus and Beutell (1985) to researchers still has merit. They specifically cautioned researchers to guard against automatically concluding that a reduction in work-family conflict would occur for employees allowed to work a more flexible schedule. Rather, it may be that it was a combination of the degree of perceived flexibility in the work schedule and its' ability to meet the specific needs of the employee that would reduce work-family 
conflict.

Replication of these findings should cause researchers to question the soundness of the current emphasis placed on alternative or flexible work schedules as a method of helping employees balance work and family demands. Perhaps manager's efforts should be redirected toward trying to find ways to reduce the work loads of their employees and increasing the amount of flexibility allowed employees in their current work schedules to handle personal/family responsibilities instead of the design and implementation of flexible work schedules. The number of hours worked may be a better predictor of work-family conflict than the type of work schedule or the degree of perceived work schedule flexibility. A reduction in the work demands that require employees to work longer hours may prove to be a more effective intervention in reducing the amount of work-family conflict experienced by employees. 
REFERENCES

Ahmadi, M., Raiszadeh, F. M. E., \& Wells, W. L. (1986). "Traditional vs. non-traditional work schedules: A case study of employee preference," Industrial Management, (March-April), 20-23.

Buckley, R. M., Kicza, D. C., \& Crane, N. (1987). "A note on the effectiveness of flextime as an organizational intervention," Public Personnel Management, 16(3), 83-97.

Burke, R. J. (1988). "Some antecedents and consequences of work-family conflict," Journal of Social Behavior and Personality, $3(4), 287-302$.

Christensen, K.E. \& Staines, G. L. (1990) . "Flextime: viable solution to work/family conflict?," Journal of Family Issues, $11(4), 455-476$.

Cicirelli, V. G. (1981). Helping elderly parents: The role of adult children, Boston: Auburn House

Dunham, R. B., Pierce, J. L., \& Castaneda, M. B. (1987). "Alternative work schedules: Two field quasi-experiments," Personnel Psychology, 40, 215-242.

Duxbury, L. \& Haines, G. Jr., (1991). "Predicting alternative work arrangements from salient attitudes: A study of decision makers in the public sector," Journal of Business Research, 23, 83-97.

Goff, S. J., Mount, M. K., \& Jamison, R. L. (1990) . "Employer supported childcare, work/family conflict, and absenteeism: A field study," Personnel Psychology, 43, 793-809.

Greenhaus, J. H., Bedeian, A. G. \& Mossholder, K.W. (1987). "Work experiences, job performance, and feelings of personal and family well-being," Journal of Vocational Behavior, 31, 200-215.

Greenhaus, J. H. \& Beutell, N. J. (1985). "Sources of conflict between work and family roles," Academy of Management Review, 10(1), 76-48. 
Greenhaus, J. H. , Parasuraman, S., Granrose, C. S., Rabinowitz, S., \& Beutell, N. J. (1989). "Sources of work-family conflict among two-career couples," Journal of Vocational Behavior, 34, 133-153.

Hicks, W. D., \& Klimoski, R. J. (1981). "The impact of flexitime on employee attitudes," Academy of Management Journal, 24(2), 333-341.

Higgins, C. A., Duxbury, L. E., \& Irving, R. H. (1992). "Work-family conflict in the dual-career family," organizational Behavior and Human Performance, 51, 51-75.

Jamieson, D. \& O'Mara, J. (1991). Managing Workforce 2000: Gaining the Diversity Advantage, san Francisco, CA: Jossey-Bass.

Kahn, R. L., Wolfe, D. M., Quinn, R., Snoek, J. D. , \& Rosenthal, R. A. (1964). organizational Stress, New York: Wiley.

Kelly, R. F. and Voydanoff, P. (1985). "Work/family strain among employed parents," Family Relations, 34, 367-374.

Kopelman, R. E., Greenhaus, J. H., \& Connolly, T. F. (1983). "A model of work, family and interrole conflict: A construct validation study," Organizational Behavior and Human Performance, 32 , 198-215.

Leigh, J. H., Lucas, G. H., Jr., \& Woodman, R. W. (1988). "Effects of perceived organizational factors on role stress-job attitude relationships," Journal of Management, 14(1), 41-58.

Loerch, K. J., Russell, J. E., \& Rush, M. C. (1989). "The relationships among family domain variables and work-family conflict for men and women," Journal of Vocational Behavior, 35, 288-308.

McGuire, J. B. \& Liro, J. R. (1987). "Absenteeism and flexible work schedules," Public Personnel Management, 16(1), 47-59.

Nord, W. R. \& Costigan, R. (1973). "Worker adjustment to the four-day week: a longitudinal study," Journal of Applied Psychology, 58(1), 60-66. 
Olmsted, B. (1983). "Changing times: the use of reduced work time options in the United States,"

International Labour Review, 122(4), 479-492.

Pleck, J. H., staines, G. L., \& Lang, L. (1980) . "Conflicts between work and family life," Monthly Labor Review, March, 29-31.

Ralston, D. A. (1989). "The benefits of flextime: Real or imagined?" Journal of organizational Behavior, 10, 369-373.

Staines, G. L. \& O'Connor, P. (1980). "Conflicts among work, leisure, and family roles," Monthly Labor Review, August, 35-39.

U.S. Department of Labor. (1992). Work and Family: Part-time employment transitions among young women, (Bureau of Labor statistics No. 824). Washington, DC: U.S. Department of Labor.

Wiley, D. L. (1987) . "The relationship between work/nonwork role conflict and job-related outcomes: Some unanticipated findings," Journal of Management, $13(3), 467-472$.

Zedeck, S. \& Mosier, K. L. (1990). and employing organization," $45(2), 240-251$.

"Work in the family American Rsychologist, 


\section{APPENDIX}

SURVEY INSTRUMENT 


\section{EMPLOYEE SURVEY}

Dear U.S. Bancorp Employee,

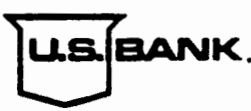

You have been randomly selected to participate in a survey conducted jointly by U.S. Bancorp and Portland State Universicy (PSU) assessing the needs for alternative work schedules at U.S. Bancorp.

The purpose of the survey is ewotold. U.S. Bancorp is incerested in assessing the benetits of alternative work schedules. 1'SU is conducting research on some of the factors that contribute to contlicts that arise between work and non-work aspects of our lives. Your voluntary participation is important to this project and we encourage you and your spousc/partncr, it applicable, to complete the enclosed surveys. There is no incent or desire to identify any individual completing the survey. Your responses will be anonvmous in that your name or specitic work group will not appear anvwhere on the survey form. The numbers you sec on the surveys are included tor the sole purpose of being able to match you and your spouse/partner's survey when they are returned. No one outside of the PSU research team will see the completed questionnaires. The PSU researchers will group the individual data (making it anonymous) and report the overall resules to U.S. Bancorp's Human Resources Group.

Supervisors and managers have been notified that a random sample of employecs will be completing surveys berween the dates of September 9-18 and that cmplovees are to be allowed company time to complete their survey in private and away from their workstations. The survey should take no longer than 30 minutes to complete. Plcase let your supervisor know if vou need any help in makmy arrangements to complete your survey. Please fill out the questionnaire marked $E$ in the upper right hand corner and give the questionnatre marked S/P to vour spouse/partner, if applicable. If a spouse/partner is also completing a survery please do not discuss individual responses prior to completion. After the surver is completed. please mal to De Hanmer at Portand State University in the enclosed selt-actdressed envelope as soon as possible.

If vou have anv questions about the survey ficel frec to contace 1)orecen (irove in Human Resources at (50)3) 275-6147. Dr Leslic Hammer or Tenora (irigsby at Poreland State University at (503) 725-3878. We appreciate your tume in helping w) wh this research project. Your input is important in understanding how people ticl about AWS at U.S. Bancorp.

sincorcli:<smiles>CCCCC(C)CCCCC1CC1C</smiles>

hadv Ruce, Executeve Vice President i luman Resources Ciroup L.S. B.ncorp

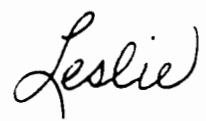

Leslic Hammir. Ph. I). Department of Pswchology Portland State University

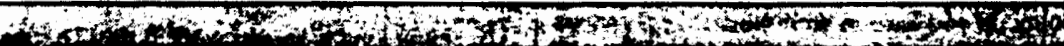


DEFINITION OF ALTERNATIVE WORK SCHEDULES (AWS):

Alternative work schedules refer to any type of non-traditional work schedule that varies in hours or days from the standard fixed schedule of eight hours a day, five days a week. Examples of AWS: are:

- Flextime: A work schedule that permits flexible starting and quitting times but requires a standard number of hours within a given time period.

- Midday Flex: One or two hours of Aexibility at midday versus begimming or end of the day.

- Professional Part-time: Exempe cmployecs work a specified number of hours below the standard work weck on a regular basis (not applicable to temporary or on-call employees).

- Part-time/Special Hourly: Nonexempt employees work a specified number of hours below the standard work weck.

- Job Sharing: Two workers voluntarily share responsibilities of onc full-rime job.

- Flexplace/Telecommuting: Employees work at home or at a satellite worksite during regular work hours; they may or may not be linked electronically through a computer

- Selectime: Voluntary, temporary, reduction of work hours for family reasons, including return from parental leave.

- Compressed Work Week: A full-time schedule is compressed into threc or four days, e.g., four ten hour or three twelve hour days (also known as $4 / 40$ or $3 / 36$ ).

\section{Employee Survey}

Please enter your answer (number) in the box provided to the right of each question. (NOTE: "Family" refers to both couples with and without children.)

1. Age:

2. Sex: 1. Female 2. Male

3. How would you best classify your present job? (Select one):
1. SVP and above
3. Other Exempt
2. Vice President
4. Nonexempt

4. How would you best classify the area in which you are assigned to work?

1. Support Group

2. Business Group

5. Job Status: 1. Full-time Salaried (FT)

2. Part-time hourly (PT)

3. Special hourly ( $\mathrm{SH})$

6. Has your job status changed in one of the following ways in the last 12 months?
1. Not changed
4. PI to $\mathrm{SH}$
7. $\mathrm{SH}$ to $\mathrm{FT}$
2. FT to PT
5. FT to $\mathrm{SH}$
8. Other
3. PT to FT
6. $\mathrm{SH}$ to PT

7. Ethnic background (Select one):
1. African American
3. Asian
5. Hispanic
2. American Indian
4. Caucasian
6. Other

8. Marital status:
1. Married and living with spouse
2. Married and living alone
3. Single and living with partner
4. Single and living alone
5. Other

9. If you are married or are living with your partner, how long have you shared a common residence?

10. How much flexibility do you have in your work schedule to handle family/personal responsibilities?
1. A lot of flexibility
3. Hardly any flexibility
2. Some flexibility
4. No fexibility at all

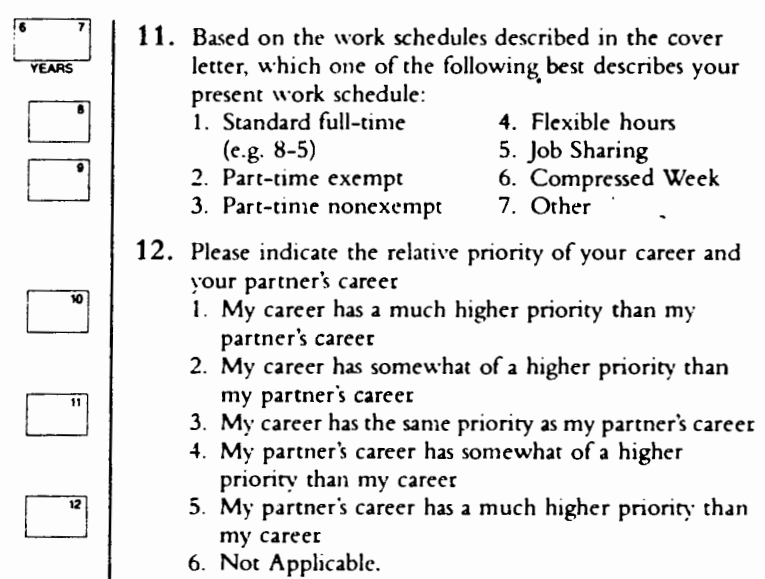

13. Two digit job grade:

14. Number of regular hours I am HIRED to work per week.

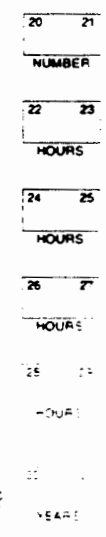


19. In the past four weeks: (Enter 0 if none):

a. How many times have you been late to work?

b. While at work, how many times have you been interrupted (c.g. telephone calls) to deal with family/personal-related issues?

c. Hou many days have you missed work due to family/personal-related issues?

20. Number of children living at home:

21. 2. Age of youngest (or only) child living at hone (if applicable):

b. Age of oldest child living at home (if applicable):

22. On the average, on days when you're working, about how much time do you spend (caking care of or). doing things with your child(ren) (if applicable)?

And about how much time on days when you're not working?

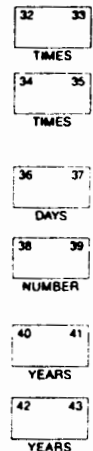

$4-45$ thans 46 HOUPS

23. Number of elderly relatives living at home

24. On the average, on days when you're working, about how much time do you spend (taking care of or) doing things with your elderly relative(s) (if applicable)?

And about how much time on days when you're not working?
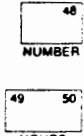

25. On the average, on days when you're working, about 53 how nuch time do you spend on home chores things like cooking, clcaning, repairs. shopping. yardwork, and kecping track of moncy and bills:

And about how much time on dav's when you're not working:

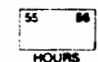

26. On the average on days when you'te working. about how much of your frec time do you spend with your spouse/partner exclusive of other inmediate family members (it applicable)?

And about how much time on days when you're not working:

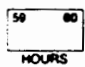

27. On the average, on days when you re working, about how much time do you spend on YOUR OWN free time activities?

And about how much time on days when you're not working:
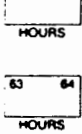

28. On the average, on days when you re working, about how much time do you spend on employmentrelated activities?

And about how much time on days when you're not working:
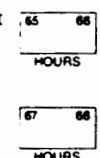

Please enter the answer (number or letter) in the box provided to the right of each question that best represents your response with respect to your IMMEDLATE HOUSEHOLD. (NOTE: "Family" refers to both couples with and without children.)

If an AWS was available to you, or you are currently on an AWS, please indicate the degree to which you agree or disagree with the following statements ranging from 1 = strongly agree to 5 = strongly disagree. If the question is Not Applicable, mark an $x$ in the NA $\square$.

29. If I were on an AWS, it would make me less likely to consider a job in another company.

30. I have problems with my child care arrangements that interfere with doing my job. NA $\square$

31. I have problenıs with commuting that interfere with ny work.

32. AWS would help ensure that I will get to work on time.

\section{NAD}

33. I have problems with elder care arrangements that interfere with doing my job. NA $\square$

STRONGLY

STRONGLY

AGREE AGREE NEUTRAL DISAGREE DISAGREE

34. If AWS were available I would spend more time focusing on work rather than on personal/family issues while at work.

35. I am satisfied with my current work schedule.

36. I am satisfied with the number of hours I work per week.

37. AWS would help decrease the number of dass I am absent from work. NA

38. AWS would help increase retention of employees.

\begin{tabular}{|c|c|c|c|c|}
\hline L & 1 & 2 & 3 & 4 \\
\hline -_ & 1 & 2 & 3 & 4 \\
\hline$\overline{8}$ & 1 & 2 & 3 & 4 \\
\hline 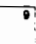 & 1 & 2 & 3 & 4 \\
\hline . & 1 & 2 & 3 & 4 \\
\hline$\overline{11}$ & 1 & 2 & 3 & 4 \\
\hline$\overline{12}$ & 1 & 2 & 3 & 4 \\
\hline $1^{-1}$ & 1 & 2 & 3 & $t$ \\
\hline$\cdot 4$ & 1 & 2 & 3 & 4 \\
\hline$\cdot$ & 1 & 2 & 3 & 4 \\
\hline
\end{tabular}


39. AWS would help decrease my level of stress on the job.

40. AWS would help increase niy ability to balance work and tantily/personal deniands.

41. AWS would help increase my job satisfaction.

42. AWS would help improve my productivity levet.

43. I feel comfortable approaching my supervisor/manager about being placed on an AWS

44. If there were more formal guidelines for AWS, I would feel comfortable approaching my supervisor/manager about being placed on an AWS

45. If 1 were provided flexibility in my job, I would be more flexible for the organizacion.

46. Workers on AWS are perceived as less committed to the organization.

47. U.S. Bancorp is concerned with helping enployees balance work and fanily/ personal demands.

48. AWS would improve customer perceptions of U.S. Bancorp's corporate inage

49. It is fair for some co-workers to be placed on AWS while others are not.

50. I would be resentful of co-workers whose jobs fit AWS if mine did not.

51. Do you manage/supervise employees? 1. Yes 2. No. If yes, then please continue. If no, then please skip to number 65 .

52. Number of employees manage/supervise:

53. AWS would increase the difficulty in how I manage people (e.g. scheduling).

54. AWS would increase the hours I spend at work.

55. I am open to employees who approach me to go on an AWS.

56. I would be more likely to implement AWS if there were formal guidelines and procedures

57. AWS should be available to employees of U.S. Bancorp at all levels.

58. AWS would help increase employee recruitment.

59. AWS would help increase employee morale.

60. AWS would help increase organizational efficiency.

61. AWS would increase my workload.

62. AWS would increase conmunication problems on the job.

63. The benefit system mav need to be modified for workers on AWS

64. Having employees on AWS would help DECREASE the dificulty of mo job

\begin{tabular}{|c|c|c|c|c|c|}
\hline & $\begin{array}{l}\text { TRONGLY } \\
\text { AGREE }\end{array}$ & AGREE & NEUTRAL I & DISAGREE & $\begin{array}{l}\text { STRONGLY } \\
\text { DISAGREEE }\end{array}$ \\
\hline 6 & 1 & 2 & 3 & 4 & 5 \\
\hline 17 & 1 & 2 & 3 & 4 & 5 \\
\hline 10 & 1 & 2 & 3 & 4 & 5 \\
\hline 19 & 1 & 2 & 3 & 4 & 5 \\
\hline$\infty$ & 1 & 2 & 3 & 4 & 5 \\
\hline 21 & 1 & 2 & 3 & 4 & 5 \\
\hline 2 & 1 & 2 & 3 & 4 & 5 \\
\hline 23 & 1 & 2 & 3 & 4 & $j$ \\
\hline 24$]$ & 1 & 2 & 3 & 4 & 5 \\
\hline 25 & 1 & 2 & 3 & 4 & 5 \\
\hline 26 & 1 & 2 & 3 & 4 & 5 \\
\hline 27 & 1 & 2 & 3 & 4 & 5 \\
\hline 20 & 1 & 2 & 3 & 4 & 5 \\
\hline 30 & 1 & 2 & 3 & 4 & 5 \\
\hline 3 & 1 & 2 & 3 & 4 & 5 \\
\hline$\left[\begin{array}{r}32 \\
{[}\end{array}\right]$ & 1 & 2 & 3 & 4 & 5 \\
\hline 33 & 1 & 2 & 3 & 4 & 5 \\
\hline [3] & 1 & 2 & 3 & 4 & 5 \\
\hline 35 & 1 & 2 & 3 & 4 & 5 \\
\hline 5 & 1 & 2 & 3 & 4 & 5 \\
\hline 5 & 1 & 2 & 3 & 4 & 5 \\
\hline 30 & 1 & 2 & 3 & 4 & 5 \\
\hline 39 & 1 & 2 & 3 & 4 & 5 \\
\hline $\begin{array}{r}-90 \\
-1\end{array}$ & 1 & 2 & 3 & 4 & ; \\
\hline-4 & 1 & 2 & $i$ & i & $=$ \\
\hline 42 & ! & 2 & 3 & 4 & 5 \\
\hline
\end{tabular}


The following questions are specific to PSU's research interest on work/non-work issues. Please enter the number in the box provided to the right of each question that best represents your response with respect to your IMMEDIATE HOUSEHOLD. (NOTE: "Family" refers to both couples with and without children.)

Indicate the degrce to which you agree or disagree with the following statements ranging from $1=$ strongly agree to $5=$ strongly disagree. If the question is Not Applicable, mark $X$ in the NA $\square$.

65. My main satistaction in lific comes from my work.

66. The most important thing that happen to me involve my work.

67. My main satisfaction in life cones from my tamily/personal life.

68. The most important things that happen to me involve my family/personal life.

69. I frequently think abouk my family/personal life when I am busy doing soncthing else.

70. I frequently think about my work when I am busy doing something clse.

71. I live, eat, and breathe ny work

72. I live, eat, and breathe my tamily/personal life.

73. My work takes up time that 1 would like to spend on my family/personal life.

74. My work schedule ofren conflicts with my family/personal life.

75. My family dislikes how often 1 am preoccupied with my work while 1 am at home. NAD

76. After work, I come home too tired to do some of the things I would like to do. STRONGLY

STRONGIY AGREE AGREe NeUtral diSAGree DISAGREE

77. On the job 1 have so much work to do that it takes away from my personal interests.

78. Because my work is demanding, at times I am irritable at home.

79. The demands of my job make it more difficult to be relaxed at hone.

80. My job makes it difficult to be the kind of partner/spouse or parent I would like to be. $\quad$ NA $\square$

81. My family/personal life takes up time that 1 would like to spend doing my work.

82. My family/personal life often conflicts with my work schedule.

83. My co-workers dislike how often I am preoccupied with my family/personal life while I am at work.

84. When I go to work, I am too tired to do some of the things I would like to do.

85. At home, I have so many responsibilities that it takes away from ny personal interests.

86. Because my family/personal life is demanding, at times I an irritable at work

87. The demands of my family/personal life make it more difficult to be relaved while at work.

88. My family/personal life makes it dificult to be the kind of worker I wontil like to be.

\begin{tabular}{|c|c|c|c|c|}
\hline 47 & 1 & 2 & 3 & 4 \\
\hline 4 & 1 & 2 & 3 & 4 \\
\hline 45 & 1 & 2 & 3 & 4 \\
\hline 46 & 1 & 2 & 3 & 4 \\
\hline 47 & 1 & 7 & 3 & \\
\hline 4 ? & 1 & 2 & 3 & 4 \\
\hline 49 & 1 & 2 & 3 & 4 \\
\hline 56 & 1 & 2 & 3 & 4 \\
\hline 51 & 1 & 2 & 3 & 4 \\
\hline 52 & 1 & 2 & 3 & 4 \\
\hline 30 & 1 & 2 & 3 & 4 \\
\hline 54 & 1 & 2 & 3 & 4 \\
\hline 5 & 1 & 2 & 3 & 4 \\
\hline 56 & 1 & 2 & 3 & 4 \\
\hline 57 & 1 & $\underline{2}$ & 3 & 4 \\
\hline 58 & 1 & 2 & 3 & 4 \\
\hline (5) & 1 & 2 & 3 & 4 \\
\hline$\infty$ & 1 & 2 & 3 & 4 \\
\hline (1) & 1 & 2 & 3 & 4 \\
\hline 62 & 1 & 2 & 3 & 4 \\
\hline 63) & & & & \\
\hline 64 & 1 & 2 & 3 & 4 \\
\hline 65 & 1 & $?$ & 3 & 4 \\
\hline 66 & 1 & 2 & 3 & 4 \\
\hline
\end{tabular}


89. I am very satisfied with $m$ y job.

STRONGLY

STRONGLY

90. My job does not measure up to the sort of job I wanted when I originally

took the job.

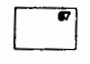

1

2

$\begin{array}{llllll}{[\infty} & 1 & 2 & 3 & 4 & 5 \\ {[\infty} & 1 & 2 & 3 & 4 & 5 \\ \square & 1 & 2 & 3 & 4 & 5\end{array}$

92. In general, I am very satisfied with the way I am spending my life these days.

93. Do you have any additional comments? Please indicate $Y$ for $Y e s$ or $N$ for No in the box provided. Attach a separate sheet if necessary:

THANK YOU FOR COMPLETING THE SURVEY.

Please return the survey in the enclosed envelope. 